\title{
Ventricular lavage for post-haemorrhagic hydrocephalus
}

\author{
Ian Pople*, Andrew Whitelaw \\ From 54th Annual Meeting of the Society for Research into Hydrocephalus and Spina Bifida \\ Vancouver, Canada. 7-10 July 2010
}

\section{Background}

Early results of an international RCT comparing drainage, irrigation \&fibrinolytic therapy (DRIFT)for prematurity-associated post-ventricular dilatation (PHVD), with standard treatment suggested no benefit in terms of avoidance of shunt dependency. There was also an increased rate of secondary bleeds in those having DRIFT. The longer term benefits or otherwise of DRIFT treatment were unknown.

\section{Materials and methods}

We randomly allocated 77 preterm infants with PHVD to either DRIFT or standard treatment (ie tapping off cerebrospinal fluid to control excessive ventricular expansion). Severe disability was assessed at 2 years' corrected age.

\section{Results}

Of 39 infants assigned to DRIFT, 21 (54\%) died or were severely disabled versus 27 of $38(71 \%)$ in the standard group (adjusted odds ratio 0.25 [95\% confidence interval: $0.08-0.82]$ ). Among the survivors, 11 of 35 (31\%) in the DRIFT group had severe cognitive disability versus 19 of 32 (59\%) in the standard group (adjusted odds ratio: 0.17 [95\% confidence interval: $0.05-0.57]$ ). Median Mental Development Index was 68 with DRIFT and_50 with standard care.

\section{Conclusions}

Despite inducing an increased rate of secondary intraventricular bleeding, DRIFT reduced severe cognitive disability in survivors and overall rates of death or severe disability. A modification of DRIFT involving

\footnotetext{
* Correspondence: ikpople@hotmail.com

Department of Neurosurgery, Frenchay Hospital, Bristol, UK. Department of Neonatal Medicine, Southmead Hospital, Bristol, UK
}

simple ventricular lavage and fibrinolytic therapy (limited to unblocking clogged-up drainage catheters) will now be employed in clinical practice at our unit.

Published: 15 December 2010

doi:10.1186/1743-8454-7-S1-S49

Cite this article as: Pople and Whitelaw: Ventricular lavage for post-

haemorrhagic hydrocephalus. Cerebrospinal Fluid Research 2010 7(Suppl 1):S49.
Submit your next manuscript to BioMed Central and take full advantage of:

- Convenient online submission

- Thorough peer review

- No space constraints or color figure charges

- Immediate publication on acceptance

- Inclusion in PubMed, CAS, Scopus and Google Scholar

- Research which is freely available for redistribution

Submit your manuscript at www.biomedcentral.com/submit

\section{() Biomed Central}

\section{Biomed Central}

